\title{
Communication
}

\section{Ochracenoids A and B, Guaiazulene-Based Analogues from Gorgonian Anthogorgia ochracea Collected from the South China Sea}

\section{Juan-Juan Zheng ${ }^{1}$, Chang-Lun Shao ${ }^{1}$, Min Chen ${ }^{1}$, Li-She Gan ${ }^{2}$, Yu-Chun Fang ${ }^{1}$, Xu-Hui Wang ${ }^{1}$ and Chang-Yun Wang ${ }^{1}$ *}

1 Key Laboratory of Marine Drugs, Ministry of Education, School of Medicine and Pharmacy, Ocean University of China, Qingdao 266003, China; E-Mails: zhengjuanjuan90@gmail.com (J.-J.Z.); shaochanglun@ouc.edu.cn (C.-L.S.); carbohydrateyu@gmail.com (M.C.); yuchunfang@ouc.edu.cn (Y.-C.F.); haiyangbencao@ouc.edu.cn (X.-H.W.)

2 Institute of Modern Chinese Medicine, College of Pharmaceutical Sciences, Zhejiang University, Hangzhou 310058, China; E-Mail: 1sgan@zju.edu.cn

* Author to whom correspondence should be addressed; E-Mail: changyun@ouc.edu.cn; Tel./Fax: +86-532-8203-1536.

Received: 24 December 2013; in revised form: 15 January 2014 / Accepted: 6 February 2014 / Published: 14 March 2014

\begin{abstract}
Two new guaiazulene-based analogues, ochracenoids A (1) and B (2), along with four known analogues (3-6), were isolated from the gorgonian Anthogorgia ochracea collected from the South China Sea. The planar structures of the new compounds were elucidated by comprehensive spectroscopic data. The absolute configuration of $\mathbf{1}$ was determined as $3 R$ by the comparison of TDDFT calculated electronic circular dichroism with its experimental spectrum. Compound $\mathbf{1}$ is a rare guaiazulene-based analogue possessing a unique $\mathrm{C}_{16}$ skeleton. The possible generation process of $\mathbf{1}$ through an intermolecular one-carbon-transfer reaction was also discussed. Compound $\mathbf{2}$ was previously described as a presumed intermediate involved in the biogenesis of anthogorgienes $\mathrm{A}$ and I. Compound 3 exhibited antiproliferative effects on the embryo development of zebrafish Danio rerio.
\end{abstract}

Keywords: gorgonian; Anthogorgia ochracea; guaiazulene-based analogue; antiproliferative effect; zebrafish embryo 


\section{Introduction}

Gorgonians have proven to be a rich source of guaiazulene-related pigments [1]. Guaiazulene-based analogues are well recognized for their distinctive blue and purple colors, which are a part of the origin of the brilliant colors of gorgonians and other organisms [2]. These compounds feature an azulene core, similar to the fused five-seven bicyclic aromatic ring system [3]. They have received much attention due to their multiple potent biological activities including antifungal, antitumor, and immunoregulatory activities and antiproliferative effects on fertilized sea urchin eggs [4,5]. In particular, a series of guaiazulene-based compounds were reported from gorgonians of Anthogorgia [2,6], and Acalycigorgia (synonymous with Anthogorgia) [4,7]. Recently, in the course of our investigation on new bioactive substances from gorgonians and soft corals as well as their derived fungi from the South China Sea [8-10], the gorgonian Anthogorgia ochracea collected from the South China Sea attracted our attention because the EtOAc extract of the gorgonian showed the presence of guaiazulene-based sesquiterpenes with characteristic UV absorption spectra (UVA $\lambda_{\max } 320-400 \mathrm{~nm}$ ) [11]. Chemical investigation on the extract led to the isolation of two new guaiazulene-based analogues, ochracenoids A (1) and B (2), and four known related analogues (3-6) (Figure 1). Herein, we report the isolation, structure elucidation, and biological activities of these compounds. As these compounds have been found to be quite labile and easily decomposable on exposure to air and light during the work-up [12], the possible generation process of $\mathbf{1}$ was also discussed.

Figure 1. Structures of compounds 1-6 and related compounds.
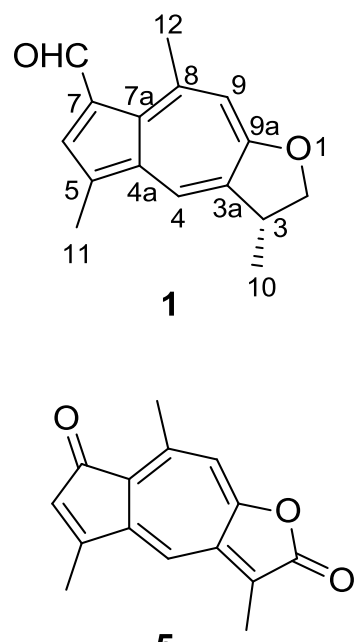

5

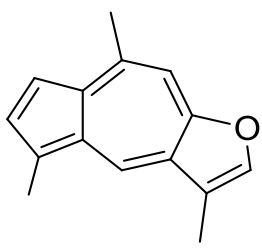

linderazulene

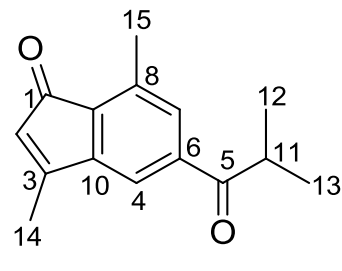

2<smiles>CC1=CC(=O)c2c1cc(C(C)C)c(C=O)c2C</smiles>

6<smiles>Cc1cc(C(=O)C(C)C)cc2c1C(=O)C[C@H]2C</smiles>

anthogorgiene A

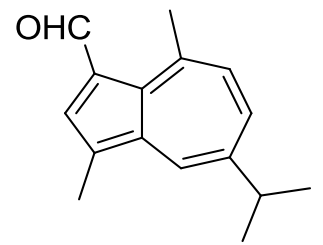

3<smiles>Cc1cc2c(cc3c(C)ccc1-3)C(C)CO2</smiles>

2,3-dihydrolinderazulene

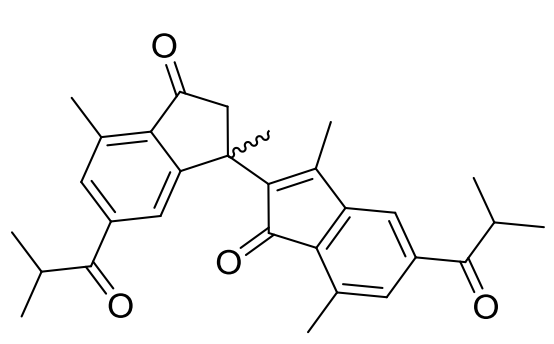

anthogorgiene I

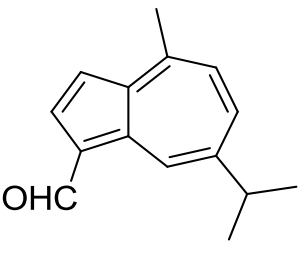

4

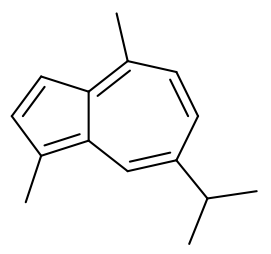

guaiazulene 


\section{Results and Discussion}

Ochracenoid A (1) was obtained as a red-purple solid. Its molecular formula of $\mathrm{C}_{16} \mathrm{H}_{16} \mathrm{O}_{2}(9$ degrees of unsaturation) was determined by HRESIMS. The IR spectrum of $\mathbf{1}$ showed an absorption band corresponding to a formyl functionality $\left(1655 \mathrm{~cm}^{-1}\right)$. The ${ }^{13} \mathrm{C}$ NMR (Table 1) spectrum indicated the presence of 16 carbon resonances including a formyl carbon $\left(\delta_{\mathrm{C}} 187.0\right)$, seven quaternary olefinic carbons $\left(\delta_{\mathrm{C}} 166.7,149.0,138.5,134.7,130.3,129.2\right.$ and 127.6), three olefinic methines $\left(\delta_{\mathrm{C}} 135.6\right.$, 131.0 and 116.0$)$, one methine $\left(\delta_{\mathrm{C}} 39.4\right)$, one methylene $\left(\delta_{\mathrm{C}} 78.1\right)$, and three methyl groups $\left(\delta_{\mathrm{C}} 30.9\right.$, 20.5 and 13.1). The ${ }^{1} \mathrm{H}$ NMR (Table 1) spectrum showed signals corresponding to two aromatic methyls $\left[\delta_{\mathrm{H}} 3.11(\mathrm{~s}, 3 \mathrm{H})\right.$ and $\left.2.55(\mathrm{~s}, 3 \mathrm{H})\right]$ and three aromatic methines $\left[\delta_{\mathrm{H}} 8.12(\mathrm{~d}, J=1.2 \mathrm{~Hz}, 1 \mathrm{H})\right.$, $7.97(\mathrm{~s}, 1 \mathrm{H})$ and $7.09(\mathrm{~s}, 1 \mathrm{H})]$. These spectroscopic data indicated that the basic skeleton of 1 should be an azulene, and the ${ }^{1} \mathrm{H}$ NMR signals for the azulene portion of 1 were similar to those of linderazulene (Figure 1) [13]. The remaining resonances, one methyl at $\delta_{\mathrm{H}} 1.49(\mathrm{~d}, J=6.6 \mathrm{~Hz})$, one methine at $\delta_{\mathrm{H}} 3.81(\mathrm{~m})$, and one methylene at $\delta_{\mathrm{H}} 4.82(\mathrm{t}, J=8.4 \mathrm{~Hz})$ and $4.27(\mathrm{dd}, J=8.4,6.6 \mathrm{~Hz})$, suggested that $\mathbf{1}$ was a 2,3-dihydro-derivative of linderazulene. The NMR spectra of $\mathbf{1}$ were nearly identical to those observed for 2,3-dihydrolinderazulene (Figure 1) [4], a guaiazulene-based analogue isolated from an Anthogorgia gorgonian. The main difference was the observation of resonances attributable to a formyl functionality $\left[\delta_{\mathrm{C}} 187.0(\mathrm{CH})\right.$ and $\delta_{\mathrm{H}} 10.61(\mathrm{~s}, 1 \mathrm{H})$ ] connected to $\mathrm{C}-7$ in 1 , supported by the HMBC correlations from $-\mathrm{CHO}$ to $\mathrm{C}-7$ and $\mathrm{C}-6$ (Figure 2), rather than an olefinic proton in 2,3-dihydrolinderazulene. The planar structure of 1 was confirmed by 2D-NMR experiments including ${ }^{1} \mathrm{H}-{ }^{1} \mathrm{H}$ COSY, HMQC, and HMBC correlations (Figure 2). Compound 1 was therefore designated as 7-formyl-2,3-dihydrolinderazulene.

Table 1. NMR spectroscopic data $\left(600 / 150 \mathrm{MHz}, \mathrm{CDCl}_{3}\right)$ for compound $\mathbf{1}$.

\begin{tabular}{cccc}
\hline Position & $\boldsymbol{\delta}_{\mathbf{H}}(\boldsymbol{J}$ in $\mathbf{H z})$ & $\boldsymbol{\delta}_{\mathbf{C}}$ Type & HMBC \\
\hline 2 & $4.82, \mathrm{t}(8.4)$ & $78.1, \mathrm{CH}_{2}$ & $\mathrm{C}-10$ \\
3 & $4.27, \mathrm{dd}(8.4,6.6)$ & & - \\
$3 \mathrm{a}$ & $3.81, \mathrm{~m}$ & $39.4, \mathrm{CH}$ & - \\
4 & - & $130.3, \mathrm{C}$ & $\mathrm{C}-3, \mathrm{C}-5, \mathrm{C}-7 \mathrm{a}, \mathrm{C}-9 \mathrm{a}$ \\
$4 \mathrm{a}$ & $8.12, \mathrm{~d}(1.2)$ & $131.0, \mathrm{CH}$ & - \\
5 & - & $138.5, \mathrm{C}$ & - \\
6 & - & $127.6, \mathrm{C}$ & - \\
7 & $7.97, \mathrm{~s}$ & $135.6, \mathrm{CH}$ & - \\
$7 \mathrm{a}$ & - & $129.2, \mathrm{C}$ & - \\
8 & - & $134.7, \mathrm{C}$ & - \\
9 & - & $149.0, \mathrm{C}$ & - \\
$9 \mathrm{a}$ & $7.09, \mathrm{~s}$ & $116.0, \mathrm{CH}$ & $\mathrm{C}-3 \mathrm{a}, \mathrm{C}-7 \mathrm{a}, \mathrm{C}-9 \mathrm{a}, \mathrm{C}-12$ \\
10 & - & $166.7, \mathrm{C}$ & $\mathrm{C}-2, \mathrm{C}-3, \mathrm{C}-3 \mathrm{a}$ \\
11 & $1.49, \mathrm{~d}(6.6)$ & $20.5, \mathrm{CH}$ & $\mathrm{C}-4 \mathrm{a}, \mathrm{C}-5, \mathrm{C}-6$ \\
12 & $2.55, \mathrm{~s}$ & $13.1, \mathrm{CH}_{3}$ & $\mathrm{C}-7 \mathrm{a}, \mathrm{C}-8, \mathrm{C}-9$ \\
$7-\mathrm{CHO}$ & $3.11, \mathrm{~s}$ & $30.9, \mathrm{CH}_{3}$ & $\mathrm{C}-6, \mathrm{C}-7$ \\
\hline
\end{tabular}


Figure 2. ${ }^{1} \mathrm{H}-{ }^{1} \mathrm{H}$ COSY and key HMBC correlations for $\mathbf{1}$ and 2.
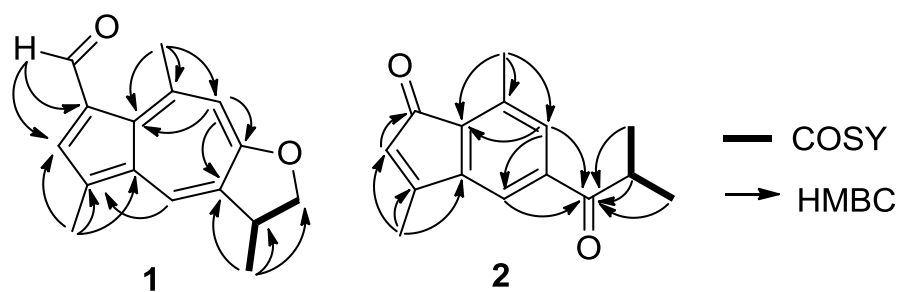

The absolute configuration of C-3 in $\mathbf{1}$ was determined by theoretical calculation of electronic circular dichroism (ECD) spectrum. Arbitrarily assigned $3 R-1$ was employed to perform a random conformational search by using the Monte Carlo method with MMFF94 force field in the Spartan 08 software package [14]. Only one lowest-energy conformer has been located within an energy cut-off of $2 \mathrm{kcal} / \mathrm{mol}$ (Figure 3). Full geometry optimization and harmonic vibrational frequencies calculation were performed at the B3LYP/6-31+G(d) level in the gas phase by using the Gaussian 09 software package [15]. The energies, oscillator strengths, and rotational strengths of the first 30 electronic excitations were calculated using the TDDFT methodology at the B3LYP/6-311++G $(2 \mathrm{~d}, 2 \mathrm{p}) / \mathrm{B} 3 \mathrm{LYP} / 6-31+\mathrm{G}(\mathrm{d})$ level in vacuum. The ECD spectra were then simulated by the overlapping Gaussian function $(\sigma=0.5 \mathrm{eV})$ [16]. In the 200-600 nm region, compared to the experimental ECD spectrum of $\mathbf{1}$, the calculated ECD spectrum of $3 R-\mathbf{1}$ showed a similar curve with positive first, negative second, positive third, and negative fourth Cotton effects at $520(+82), 375(-1), 303(+15)$, and $254(-20) \mathrm{nm}$, respectively (Figure 3). Although there were some large wavelength differences between experimental Cotton effects and the corresponding theoretical ones, especially the first Cotton effect, due to idealized modeling and simulation, qualitative analyses of the results allowed the assignments of the experimental first positive Cotton effect around $438 \mathrm{~nm}$ to the predicted first positive electronic excitation at $491 \mathrm{~nm}$, the experimental second negative Cotton effect around $376 \mathrm{~nm}$ to the predicted 2nd-5th negative electronic excitations at 391, 375, 339, and $339 \mathrm{~nm}$, and so on (Figure 3). Base on the above assignments, the absolute configuration at C-3 in $\mathbf{1}$ was determined as $R$.

Ochracenoid B (2) was obtained as a yellow solid, with a molecular formula of $\mathrm{C}_{15} \mathrm{H}_{16} \mathrm{O}_{2}$ ( 8 degrees of unsaturation) determined by HRESIMS. The ${ }^{1} \mathrm{H}$ NMR spectrum (Table 2) indicated the presence of three aromatic methines $\left[\delta_{\mathrm{H}} 7.61(\mathrm{brs}, 1 \mathrm{H}), 7.48(\mathrm{brs}, 1 \mathrm{H})\right.$ and $\left.5.76(\mathrm{~s}, 1 \mathrm{H})\right]$, one methine $\left[\delta_{\mathrm{H}} 3.52\right.$ (septet, $J=8.5 \mathrm{~Hz}, 1 \mathrm{H})]$, and four methyls $\left[\delta_{\mathrm{H}} 2.58(\mathrm{~s}, 3 \mathrm{H}), 2.27(\mathrm{~s}, 3 \mathrm{H})\right.$ and $\left.1.23(\mathrm{~d}, J=8.5 \mathrm{~Hz}, 6 \mathrm{H})\right]$. The ${ }^{13} \mathrm{C}$ NMR and DEPT spectra showed 15 carbon signals, including two ketones $\left(\delta_{\mathrm{C}} 204.2\right.$ and 198.3), five quaternary olefinic carbons $\left(\delta_{\mathrm{C}} 161.1,146.7,139.9,136.6\right.$ and 131.2), three olefinic methines $\left(\delta_{\mathrm{C}} 133.4,125.2\right.$ and 116.5$)$, one methine $\left(\delta_{\mathrm{C}} 35.9\right)$, and four methyl groups $\left(\delta_{\mathrm{C}} 19.2,19.2\right.$, 17.3 and 14.2). The HMQC spectrum assigned all protonated carbons. These spectroscopic features suggested that 2 was structurally related to anthogorgiene A (Figure 1) [2]. The evident difference was that two $\mathrm{sp}^{2}$ olefinic carbons attributed to C-2 and C-3 presented in $\mathbf{2}$ instead of two $\mathrm{sp}^{3}$ carbons corresponding in anthogorgiene A. On the basis of 2D NMR analyses (Figure 2), an indenone nucleus was established. The methyl substitutions at C-3 and C-8 were confirmed by HMBC correlations from $\mathrm{H}_{3}-14$ to $\mathrm{C}-2, \mathrm{C}-3$ and $\mathrm{C}-10$, and from $\mathrm{H}_{3}-15$ to C-7, C-8 and C-9, respectively. The presence of an isobutanoyl group was recognized from the ${ }^{1} \mathrm{H}-{ }^{1} \mathrm{H}$ COSY correlations between a methine proton $\left(\delta_{\mathrm{H}} 3.52\right)$ and two methyl protons $\left(\delta_{\mathrm{H}} 1.23\right)$, together with the HMBC interactions from the methyl and 
methine protons to the ketone $\left(\delta_{\mathrm{C}} 204.2, \mathrm{C}-5\right)$. The linkage of the isobutanoyl group to C-6 was deduced by the HMBC correlations from H-4 and H-7 to C-5. Thus the structure of 2 was established as 3,8-dimethyl-6-isobutanoylindenone.

Figure 3. B3LYP/6-311++G(2d,2p)/B3LYP/6-31+G(d) calculated electronic circular dichroism (ECD) spectrum of $3 R-\mathbf{1}$ (red) and the experimental ECD spectrum of $\mathbf{1}$ (black).

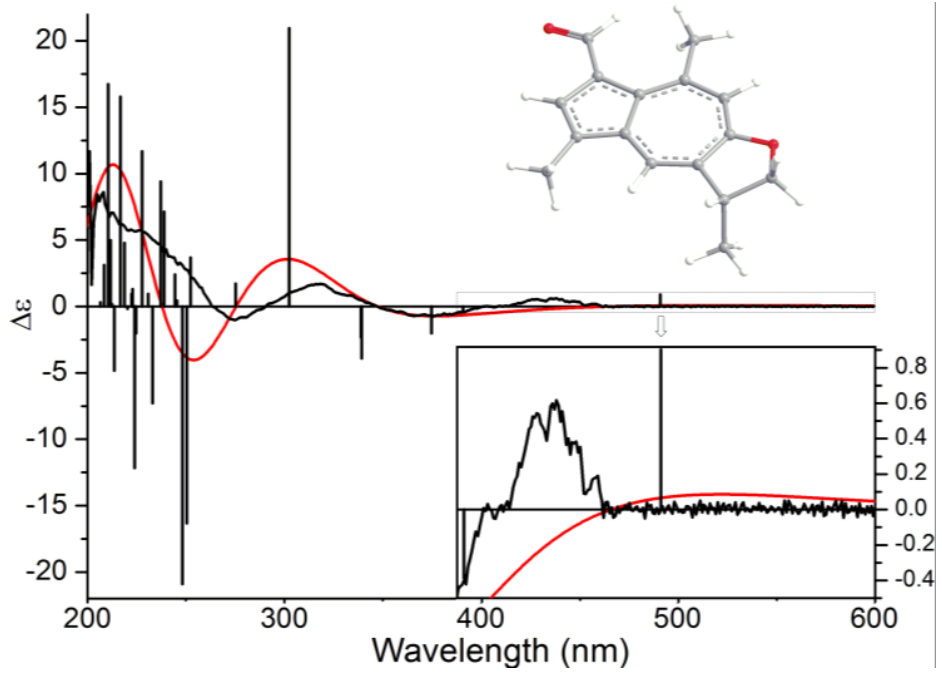

Table 2. NMR Spectroscopic Data (500/125 MHz, $\left.\mathrm{CDCl}_{3}\right)$ for compound 2.

\begin{tabular}{cccc}
\hline Position & $\boldsymbol{\delta}_{\mathbf{H}}(\boldsymbol{J}$ in Hz $)$ & $\boldsymbol{\delta}_{\mathbf{C}}$ Type & HMBC \\
\hline 1 & - & $198.3, \mathrm{C}$ & - \\
2 & $5.76, \mathrm{~s}$ & $125.2, \mathrm{CH}$ & $\mathrm{C}-1, \mathrm{C}-3, \mathrm{C}-9, \mathrm{C}-10, \mathrm{C}-14$ \\
3 & - & $146.7, \mathrm{C}$ & - \\
4 & $7.48, \mathrm{brs}$ & $116.5, \mathrm{CH}$ & $\mathrm{C}-5, \mathrm{C}-7, \mathrm{C}-9, \mathrm{C}-10$ \\
5 & - & $204.2, \mathrm{C}$ & - \\
6 & - & $139.9, \mathrm{C}$ & - \\
7 & $7.61, \mathrm{brs}$ & $133.4, \mathrm{CH}$ & $\mathrm{C}-4, \mathrm{C}-5, \mathrm{C}-9, \mathrm{C}-15$ \\
8 & - & $136.6, \mathrm{C}$ & - \\
9 & - & $131.2, \mathrm{C}$ & - \\
10 & - & $161.1, \mathrm{C}$ & - \\
11 & 3.52, septet $(8.5)$ & $35.9, \mathrm{CH}$ & $\mathrm{C}-5, \mathrm{C}-12, \mathrm{C}-13$ \\
12 & $1.23, \mathrm{~d}(8.5)$ & $19.2, \mathrm{CH}$ & $\mathrm{C}-5, \mathrm{C}-11, \mathrm{C}-13$ \\
13 & $1.23, \mathrm{~d}(8.5)$ & $19.2, \mathrm{CH}_{3}$ & $\mathrm{C}-5, \mathrm{C}-11, \mathrm{C}-12$ \\
14 & $2.27, \mathrm{~s}$ & $14.2, \mathrm{CH}_{3}$ & $\mathrm{C}-2, \mathrm{C}-3, \mathrm{C}-10$ \\
15 & $2.58, \mathrm{~s}$ & $17.3, \mathrm{CH}_{3}$ & $\mathrm{C}-7, \mathrm{C}-8, \mathrm{C}-9$ \\
\hline
\end{tabular}

The structures of known compounds, 1-formylguaiazulene (3) [17], 1-formyl-4-methyl-7-iso propylazulene (4) [18], ketolactone (5) [19], and 3,8-dimethyl-5-isopropyl-6-formylindenone (6) [20] were elucidated by NMR spectroscopic data and comparison with those previously reported in the literature.

A literature survey revealed that guaiazulene and related compounds could gradually suffer autoxidation even on standing at room temperature to give various products [21]. In the present study, guaiazulene-based analogues, including two $\mathrm{C}_{16}$-guaiazulene analogues (1 and $\mathbf{3}$ ), two indenone 
derivatives (2 and 6), and two common guaiazulenes (4 and 5), were obtained simultaneously. Compound $\mathbf{5}$ was reported to be a photo-oxidation product derived from linderazulene [22]. Compounds 3, 4, and 6 were described to be generated from the same precursor guaiazulene (Figure 1) and followed by an intermolecular one-carbon-transfer reaction, a side-chain oxidation, and a rearrangement to indenone derivatives, respectively [23]. Interestingly, guaiazulene-based sesquiterpenes commonly have fifteen carbon atoms, while $\mathbf{1}$, as well as $\mathbf{3}$, contained a unique $\mathrm{C}_{16}$ skeleton. Based on the fact that $\mathbf{1}$ is constructed by a guaiazulene sesquiterpene moiety, 2,3-dihydrolinderazulene, with an additional formyl attached at C-7, a possible oxidative transformation process from 2,3-dihydrolinderazulene to 1 was proposed in Scheme 1. By the attack of oxygen, 2,3-dihydrolinderazulene was considered to initially form an electron-transfer complex, followed by the conformation of two tautomeric dimers in equilibrium [2,21,23]. Then the unique tautomers constituted the important intermediates (Scheme 1, a and b) by exposure to air at room temperature. Finally, the intermediates were converted into $\mathbf{1}$ by an intermolecular one-carbon-transfer reaction to form the additional formyl group [21,23]. In the literature, $\mathbf{2}$ was described as a presumed intermediate involved in the biogenesis of anthogorgienes A and I (Figure 1), and was depicted to be derived from guaiazulene via a $\mathrm{C}-1$ and $\mathrm{C}-5$ peroxidated intermediate to follow a 4,5,6-cyclopropane formation and then cleavage of the C-4/C-5 bond [2]. The isolation of 2 gave evidence to the deduction of the generation process from guaiazulene to anthogorgienes $\mathrm{A}$ and $\mathrm{I}$.

Scheme 1. Possible transformation process from 2,3-dihydrolinderazulene to 1.

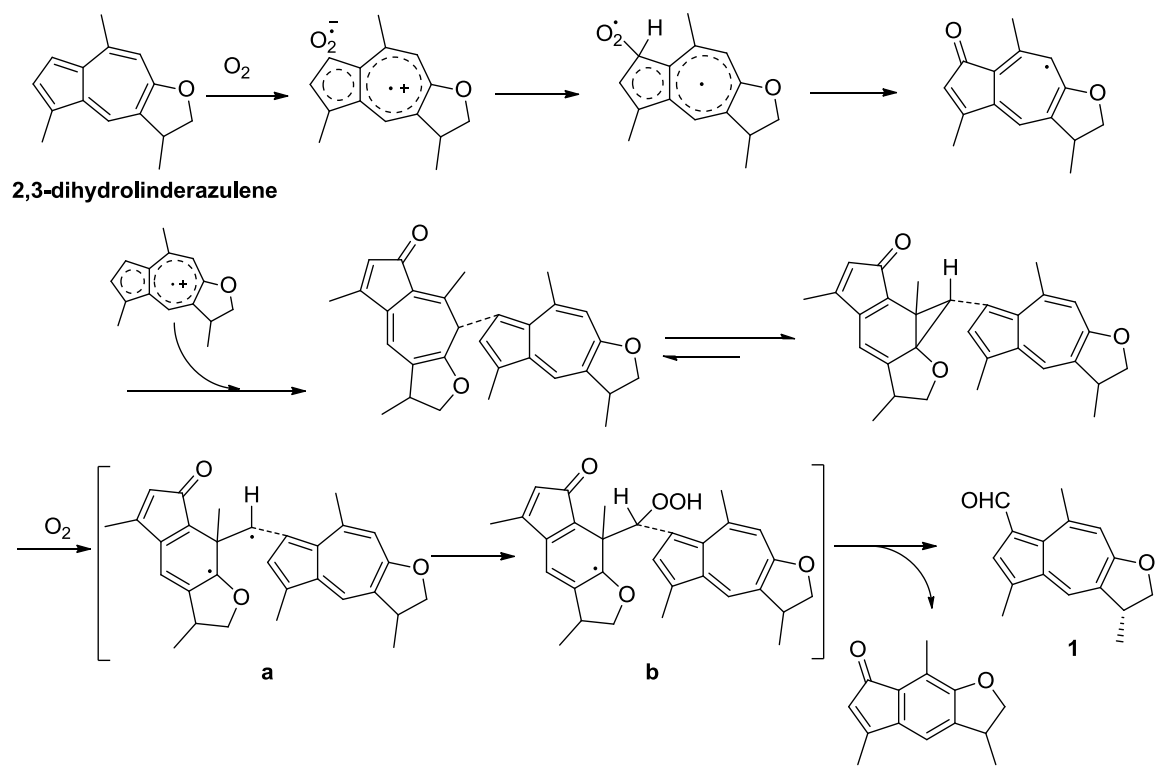

All the isolated compounds were evaluated for their antiproliferative effects on zebrafish embryo. It should be pointed out that the developing zebrafish Danio rerio is an in vivo pharmacologically relevant model which provides rapid and high throughput screening (HTS) for compounds with capability of reducing cell proliferation [24]. Compound 3 showed strong antiproliferative effects leading to abnormal several aspects of the embryonic development including coagulated eggs (48 h), notochord malformation $\left(72 \mathrm{~h}\right.$ ), and embryo death $(72 \mathrm{~h})$ with the $\mathrm{EC}_{50}$ values of 3.98, 6.50, and $7.39 \mu \mathrm{M}$, respectively, while compounds 1, $\mathbf{2}$ and 4-6 exhibited no antiproliferative effects on zebrafish embryo. 
The isolated compounds were also evaluated for their cytotoxicities and antibacterial activities. However, no compound showed any cytotoxicity against five human tumor cell lines (HeLa, A-549, HCT-116, HL-60, and K562) and antibacterial activity on six strains of pathogenic bacteria.

More details are available at the Supplementary Information.

\section{Materials and Methods}

\subsection{General Experimental Procedures}

Melting points were determined on an X-6 micromelting point apparatus and are uncorrected (Beijing CBIO Bioscience \&Technologies Co., Ltd., Beijing, China). Optical rotations were measured on a JASCO P-1020 digital polarimeter (JASCO Corporation, Tokyo, Japan). IR spectra were recorded on a Nicolet-Nexus-470 spectrometer (International Equipment Trading Ltd., Vernon Hills, IL, USA) using $\mathrm{KBr}$ pellets. UV spectra were obtained on a Beckman DU 640 spectrophotometer (Beckman Coulter Inc., Brea, CA, USA). ECD spectrum was recorded on a JASCO J-810 circular dichroism spectrometer (JASCO Corporation, Tokyo, Japan). NMR spectra of compounds $\mathbf{1}$ and 3-5 were recorded on a JEOL JNM-ECP NMR spectrometer (JEOL Ltd., Tokyo, Japan; $600 \mathrm{MHz}$ for ${ }^{1} \mathrm{H}$ and $150 \mathrm{MHz}$ for ${ }^{13} \mathrm{C}$ ), and NMR spectra of 2 and 6 were recorded on an Agilent DD2 $500 \mathrm{MHz}$ NMR spectrometer (Agilent Technologies, Inc., CA, USA; $500 \mathrm{MHz}$ for ${ }^{1} \mathrm{H}$ and $125 \mathrm{MHz}$ for ${ }^{13} \mathrm{C}$ ). Chemical shifts $(\delta)$ were reported in ppm, using TMS as internal standard and coupling constants $(J)$ were in Hz. ESIMS and HRESIMS were measured on a Micromass Q-TOF spectrometer (Thermo Fisher Scientific Inc., Waltham, MA, USA). HPLC separation was performed using a Hitachi prep-HPLC system coupled with a Hitachi L-2455 diode array detector. A Kromasil $\mathrm{C}_{18}$ preparative HPLC column $(250 \times$ $10 \mathrm{~mm}, 5 \mu \mathrm{m}$ ) was used (Hitachi Corporation, Tokyo, Japan). Silica gel (Qing Dao Hai Yang Chemical Group Co.; Qing Dao, China; 200-300 mesh), Sephadex LH-20 (Amersham Biosciences Inc., Piscataway, NJ, USA) and octadecylsilyl silica gel (Unicorn, Merck KGaA, Darmstadt, Germany; 45-60 $\mu \mathrm{m}$ ) were used for column chromatography. Precoated silica gel plates (Yan Tai Zi Fu Chemical Group Co., Yan Tai, China; G60, F-254) were used for thin layer chromatography.

\subsection{Materials}

The gorgonian Anthogorgia ochracea GXWZ-07 (1.9 kg, wet weight) was collected from the coral reef of Weizhou Island in the South China Sea, China, in April 2011, and was identified by Dr. Xiu-Bao Li, South China Sea Institute of Oceanology, Chinese Academy of Science.

\subsection{Extraction and Isolation}

The gorgonian $A$. ochracea was cut into small pieces and exhaustively extracted with $\mathrm{CH}_{2} \mathrm{Cl}_{2} / \mathrm{MeOH}$ $(v: v, 1: 1)$ three times $(3 \times 2000 \mathrm{~mL})$ at room temperature, and the solvent was evaporated in vacuo. The organic layer was filtered and concentrated under reduced pressure to give a residue ( $36.2 \mathrm{~g})$, which was partitioned between EtOAc and $\mathrm{H}_{2} \mathrm{O}(v: v, 2: 1)$ for three times. The EtOAc extract was concentrated in vacuo to afford $20 \mathrm{~g}$ of EtOAc residue, which was subjected to column chromatography (CC) on silica gel, using EtOAc-petroleum ether (0\%-100\%) as eluent. By combining the fractions with TLC monitoring, six fractions (Fr.1-Fr.6) were obtained. Fr.3 (1.2 g) was 
fractionated over silica gel CC eluted with EtOAc-petroleum ether gradients (10\%-90\%) to afford four sub-fractions (Fr.3.1-Fr.3.4). Repeated chromatography of Fr.3.3 using Sephadex LH-20 eluted with petroleum ether/ $\mathrm{CH}_{2} \mathrm{Cl}_{2} / \mathrm{MeOH}(v: v: v, 2: 1: 1)$ provided Fr.3.3.1-Fr.3.3.3. Fr.3.3.1 was purified by ODS $\mathrm{CC}$ eluted with $\mathrm{MeOH}$ to yield $2(4.5 \mathrm{mg}), 3(6 \mathrm{mg})$ and 6 (5.3 $\mathrm{mg})$. Fr.3.3.2 was purified by semi-preparative HPLC $\left(90 \% \mathrm{MeOH}-\mathrm{H}_{2} \mathrm{O}\right)$ to obtain $4(4.3 \mathrm{mg})$. Fr.3.3.3 was purified by semi-preparative HPLC $\left(60 \% \mathrm{MeOH}_{-} \mathrm{H}_{2} \mathrm{O}\right)$ to obtain $1(2.0 \mathrm{mg})$ and $5(3.5 \mathrm{mg})$.

Ochracenoid A (1): red-purple solid; m.p. 299-301 ${ }^{\circ} \mathrm{C}$; $[\alpha]^{25}{ }_{\mathrm{D}}+30.7\left(c 0.1, \mathrm{CH}_{2} \mathrm{Cl}_{2}\right)$; UV (MeOH) $\lambda_{\max }(\log \varepsilon): 230$ (3.91), 339 (3.89), 410 (3.36) nm; CD (0.10 mM, MeOH) $\lambda_{\max }(\Delta \varepsilon) 278(-0.96)$, $316(+1.07), 384(-0.73)$ and $432(+0.52) \mathrm{nm}$; IR $(\mathrm{KBr}) v_{\max } 2337,1655,1530$ and $1050 \mathrm{~cm}^{-1}$; ${ }^{1} \mathrm{H} \mathrm{NMR}\left(\mathrm{CDCl}_{3}, 600 \mathrm{MHz}\right)$ and ${ }^{13} \mathrm{C} \mathrm{NMR}\left(\mathrm{CDCl}_{3}, 150 \mathrm{MHz}\right)$, see Table 1; ESIMS $\mathrm{m} / z 241.1[\mathrm{M}+\mathrm{H}]^{+}$; HRESIMS $m / z\left[\mathrm{M}+\mathrm{H}^{+} 241.1223\right.$ (calcd for $\mathrm{C}_{16} \mathrm{H}_{17} \mathrm{O}_{2}, 241.1223$ ).

Ochracenoid B (2): yellow solid; m.p. 202-204 ${ }^{\circ} \mathrm{C}$; UV (MeOH) $\lambda_{\max }(\log \varepsilon$ ): 206 (3.96), 248 (4.01), 330 (3.22) nm; IR (KBr) $v_{\max } 1715,1697,1635,1445$ and $1210 \mathrm{~cm}^{-1} ;{ }^{1} \mathrm{H} \mathrm{NMR}\left(\mathrm{CDCl}_{3}, 500 \mathrm{MHz}\right)$ and

${ }^{13} \mathrm{C} \mathrm{NMR}\left(\mathrm{CDCl}_{3}, 125 \mathrm{MHz}\right)$ see Table 2; ESIMS $m / z 229.2[\mathrm{M}+\mathrm{H}]^{+}$; HRESIMS $m / z[\mathrm{M}+\mathrm{H}]^{+}$ 229.1223 (calcd for $\mathrm{C}_{15} \mathrm{H}_{17} \mathrm{O}_{2}, 229.1223$ ).

\subsection{Biological Assays}

The antiproliferative effects on zebrafish Danio rerio embryo were evaluated according to the described methods [25]. 3,4-Dichloroaniline was used as a positive control.

The cytotoxicities were evaluated for against human cervical carcinoma HeLa, human lung carcinoma A-549, and human colorectal cancer HCT-116 cell lines using SRB method [26] and human myeloid leukemia HL-60, and human leukemia K562 cell lines using MTT method [27]. Adriamycin was used as a positive control.

The antibacterial activities against six bacterial strains, Staphylococcus epidermidis, S. aureus, Bacillus subtilis, B. cereus, Tetragenococcus halophilus, and Kocuria rhizophila, were determined by a serial dilution technique using 96-well microtiter plates [28]. Ciprofloxacin was used as a positive control.

\section{Conclusions}

In summary, six guaiazulene-based analogues were obtained from a gorgonian Anthogorgia ochracea collected from the South China Sea. The planar structures of the new compounds (1 and 2) were elucidated by comprehensive spectroscopic data and the absolute configuration of $\mathbf{1}$ was determined by the comparison of TDDFT calculated electronic circular dichroism with its experimental spectrum. Compound $\mathbf{1}$ is a rare guaiazulene-based analogue possessing a unique $\mathrm{C}_{16}$ skeleton. A possible generation process of $\mathbf{1}$ through an intermolecular one-carbon-transfer reaction was also discussed. Compound 2 was previously described as a presumed intermediate involved in the biogenesis of anthogorgienes A and I. Compound 3 showed strong antiproliferative effects on the embryo development of zebrafish Danio rerio. 


\section{Acknowledgments}

This work was supported by the National Natural Science Foundation of China (Nos. 41176121; 41130858; 41322037; 81172977), the National High Technology Research and Development Program of China (863 Program) (2013AA093001), and the Program for New Century Excellent Talents in University, Ministry of Education of China (No. NCET-11-0472).

\section{Author Contributions}

J.-J. Zheng contribute to extraction, isolation and identification and manuscript preparation; C.-L. Shao contribute to structure elucidation; M. Chen contribute to NMR analysis; L.-S. Gan contribute to ECD calculation; Y.-C. Fang contribute to ECD test; X.-H. Wang contribute to bioactivities test; C.-Y. Wang was the project leader organizing and guiding the experiments and manuscript writing.

\section{Conflicts of Interest}

The authors declare no conflict of interest.

\section{References}

1. Faulkner, D.J. Marine natural products. Nat. Prod. Rep. 2001, 18, 1-49.

2. Chen, D.W.; Yu, S.J.; Ofwegen, L.V.; Proksch, P.; Lin, W.H. Anthogorgienes A-O, new guaiazulene-derived terpenoids from a Chinese gorgonian Anthogorgia species, and their antifouling and antibiotic activities. J. Agric. Food Chem. 2012, 60, 112-123.

3. Matsubara, Y.; Takekuma, S.; Yokoi, K.; Yamamoto, H.; Nozoe, T. Autoxidation of guaiazulene and 4,6,8-trimethylazulene in polar aprotic solvent: Structural proof for products. Bull. Chem. Soc. Jpn. 1987, 60, 1415-1428.

4. Sakemi, S.; Higa, T. 2,3-Dihydrolinderazulene, a new bioactive azulene pigment from the gorgonian Acalycigorgia sp. Experientia 1987, 43, 624-625.

5. Tanaka, J.; Miki, H.; Higa, T. Echinofuran, a new furanosesquiterpene from the gorgonian Echinogorgia praelonga. J. Nat. Prod. 1992, 55, 1522-1524.

6. Chen, D.W.; Liu, D.; Shen, S.; Cheng, W.; Lin, W.H. Terpenoids from a Chinese gorgonian Anthogorgia sp. and their antifouling activities. Chin. J. Chem. 2012, 30, 1459-1463.

7. Ochi, M.; Kataoka, K.; Tatsukawa, A.; Kotsuki, H.; Shibata, K. Gorgiabisazulene and gorgiagallylazulene, two new guaiazulenoid pigments from a gorgonian Acalycigorgia sp. Chem. Lett. 1993, 22, 2003-2006.

8. Wang, C.Y.; Zhao, J.; Liu, H.Y.; Shao, C.L.; Liu, Q.A.; Liu, Y.; Gu, Y.C. Two new eicosanoids with a unique isovalerianic acid ester moiety from the south China sea gorgonian Dichotella gemmacea. Lipids 2011, 46, 81-85.

9. Li, L.; Sheng, L.; Wang, C.Y.; Zhou, Y.M.; Huang, H.; Li, X.B.; Li, J.; Mollo, E.; Gavagnin, M.; Guo, Y.W. Diterpenes from the Hainan soft coral Lobophytum cristatum Tixier-Durivault. J. Nat. Prod. 2011, 74, 2089-2094. 
10. Shao, C.L.; Wu, H.X.; Wang, C.Y.; Liu, Q.A.; Xu, Y.; Wei, M.Y.; Qian, P.Y.; Gu, Y.C.; Zheng, C.J.; She, Z.G.; et al. Potent antifouling resorcylic acid lactones from the gorgonian-derived fungus Cochliobolus lunatus. J. Nat. Prod. 2011, 74, 629-633.

11. Struwe, M.; Csato, M.; Singer, T.; Gocke, E. Comprehensive assessment of the photomutagenicity, photogenotoxicity and photo(cyto)toxicity of azulene. Mutat. Res. 2011, 723, 129-133.

12. Manzo, E.; Ciavatta, M.L.; Lopez Gresa, M.P.; Gavagnin, M.; Villani, G.; Naik, C.G.; Cimino, G. New bioactive hydrogenated linderazulene-derivatives from the gorgonian Echinogorgia complexa. Tetrahedron Lett. 2007, 48, 2569-2571.

13. Imre, S.; Thomson, R.H.; Yalhi, B. Linderazulene, a new naturally occurring pigment from the gorgonian Paramuricea chamaeleon. Experientia 1981, 37, 442-443.

14. Spartan 08. Available online: http://www.wavefun.com/products/macintosh/Essential/ mac_essential.html (accessed on 2 August 2009).

15. Gaussian 09. Available online: http://www.gaussian.com/g_prod/g09.htm (accessed on 23 April 2013).

16. Stephens, P.J.; Harada, N. ECD Cotton effect approximated by the Gaussian curve and other methods. Chirality 2010, 22, 229-233.

17. Sato, K.; Ozu, T.; Takenaga, N. Solvent-free synthesis of azulene derivatives via Passerini reaction by grinding. Tetrahedron Lett. 2013, 54, 661-664.

18. Koul, S.K.; Taneja, S.C.; Ibraham, S.P.; Dhar, K.L.; Atal, C.K. A C-formylated azulene from Lactarius deterrimus. Phytochemistry 1985, 24, 181-182.

19. Talzhanov, N.A.; Raldugin, V.A.; Shakirova, G.A.; Adekenov, S.M. Formation of an unusual guaiane ketopentaenolide from dehydroisoleucomisin by the action of anhydrous $\mathrm{DMF}$ and $\mathrm{HCl}$. Chem. Nat. Compd. 2005, 41, 420-422.

20. Nozoe, T.; Takekuma, S.; Doi, M.; Matsubara, Y.; Yamamoto, H. Oxidation of azulene derivatives. Autoxidation of guaiazulene in a polar aprotic solvent. Chem. Lett. 1984, 13, 627-630.

21. Matsubara, Y.; Takekuma, S.; Yamamoto, H.; Nozoe, T. 6-(3-Guaiazulenyl)-5-isopropyl-3,8-di methyl-1 $(6 H)$-azulenone and its norcaradiene-isomer. Key intermediates for novel intermolecular one-carbon transfer in autoxidation of guaiazulene. Chem. Lett. 1987, 16, 455-458.

22. Alpertunga, B.; Imre, S.; Cowe, H.J.; Cox, P.J.; Thomson, R.H. A photo artefact from linderazulene. Tetrahedron Lett. 1983, 24, 4461-4462.

23. Takekuma, S.; Matsubara, Y.; Yamamoto, H.; Nozoe, T. Autoxidation of solid guaiazulene and of the solution in DMF in the presence of base or acid: A comparative study of the product distribution. Bull. Chem. Soc. Jpn. 1988, 61, 475-481.

24. Stoletov, K.; Klemke, R. Catch of the day: Zebrafish as a human cancer model. Oncogene 2008, 27, 4509-4520.

25. Parng, C.; Seng, W.L.; Semino, C.; McGrath, P.A. Zebrafish: A preclinical model for drug screening. Assay Drug Dev. Technol. 2002, 1, 41-48.

26. Skehan, P.A.; Storeng, R.; Monks, A.; McMahon, J.; Vistica, D.; Warren, J.T.; Bokesch, H.; Kenney, S.; Boyd, M.R. New colorimetric cytotoxicity assay for anticancer-drug screening. J. Natl. Cancer Inst. 1990, 82, 1107-1112. 
27. Alley, M.C.; Scudiero, D.A.; Monks, A.; Hursey, M.L.; Czerwinski, M.J.; Fine, D.L.; Abbott, B.J.; Mayo, J.G.; Shoemaker, R.H.; Boyd, M.R. Feasibility of drug screening with panels of human tumor cell lines using a microculture tetrazolium assay. Cancer Res. 1988, 48, 589-601.

28. Pierce, C.G.; Uppuluri, P.; Teistan, A.R.; Wormley, J.F.L.; Mowat, E.; Ramage, G.; Lopez-ribot, J.L. A simple and reproducible 96-well plate-based method for the formation of fungal biofilms and its application to antifungal susceptibility testing. Nat. Protoc. 2008, 3, 1494-1500.

(C) 2014 by the authors; licensee MDPI, Basel, Switzerland. This article is an open access article distributed under the terms and conditions of the Creative Commons Attribution license (http://creativecommons.org/licenses/by/3.0/). 